\title{
IMPACT OF FACTORS AFFECTING PURCHASE INTENTION OF COUNTERFEIT PRODUCTS
}

\begin{abstract}
Adeel Ashraf ${ }^{1}$
ABSTRACT

This research paper is based on investigating the factors affecting the purchasing decision of counterfeit product consumers in the city of Karachi. The study was conducted through convenient sampling by developing a questionnaire based on behavioural as well as demographic questions. The questionnaire was circulated through the social mediums and feedback was collected to carry out statistical tests for the conclusion purpose. A total of 87 responses were received through the survey questionnaire. Descriptive statistics and regression analysis were conducted to deduce quantitative inferences. The findings of the study will be helpful in planning and executing the production of CF products. The study provides data related to the buying behaviour of the CF product's consumers and the scale of sales as to how often they are sold. The study also helps focus on the need for modifications in CF products as to how much extent the consumers want modifications. This will also help the firms or brands producing CF products to launch modified versions of CF products with competitive prices, availability, and customer preferences.
\end{abstract}

Keywords: Counterfeit Products; Purchase Decision; Replica; Brand Image; Social Influence.

\section{INTRODUCTION}

Counterfeit Products (CF) have an interesting history since the advent of technological advancements and marketing innovations. These products are often purchased within different communities and societies. Thus, their demand exists in the market. People buy them with different views and opinions in their minds to utilize these products. The purchasing power is also one of the factor which contribute towards the purchase of counterfeit products as they are cheaper than

\footnotetext{
${ }^{1}$ Institute of Business Management, Karachi, Pakistan. Email: adeelashraf159@gmail.com
} 
the original products. Moreover, people take interest in the word of mouth which is the best and the most popular way of making decision before buying any product. Whether the suggestions are good or bad and how the consumers feel, they will purchase these CF products (Nia \& Zaichkowsky, 2000).

People nowadays are mainly attracted by the location of the store where these products are sold and their physical appeal rather than focusing on whether these products are replica, second class or third class. The brand name placed on the CF products somehow helps them in decision making and results in the increased sales of these products (d'Astous \& Gargouri, 2001).

This research study is conducted to point out the possible factors contributing towards the purchase intention of the counterfeit products. Moreover, it also focuses on the impact of these individual factors as to what extent these factors contribute towards the buying decisions. Risk factors are being judged like the contribution of frauds while buying the CF products. Also, the quality is of main concern as well as the customer's satisfaction is very important from the sales perspective.

\section{RESEARCH SCOPE}

This research study focuses on the lateral working regarding the demand and sales of the counterfeit products which can be conducted considering the results obtained. These workings will be helpful in planning and execution of the production. The study provides the data related to the buying behavior of the CF product's consumers and the scale of sales as how often they are sold. The study also helps to focus on the modification needs of the CF products as to how much extent the consumers want modifications. This will also help the firms or brands producing CF products to launch modified versions of CF products with competitive prices, availability, and customer's priorities.

\section{STATEMENT OF THE PROBLEM}

As mentioned earlier, CF products targeted mostly the people who cannot afford the original expensive branded products. Basically, they introduced budget constraints, affordability and personality brand image which significantly contributes toward the CF and original products. Due to the lack of knowledge about these products, consumers are less trusted in these products. They are very much concerned about the frauds and deception as they cannot afford to buy original 
products (Nguyen \& Tran, 2013). The study observations found that around 30\% of people use original products, either these are original or CF products. $70 \%$ respondents mentioned that the status que and the value same as to the original products were not decreased by the extensive availability of CF products (Nia \& Zaichkowsky, 2000). The counterfeiting of luxury products with real brand names is a real problem in Pakistan. ICC stated that the amount affected the sufferers of counterfeit products exceeds $\$ 200$ billion in 1996 and accounted 5\% of world trade (Tom, Garibaldi, Zeng, \& Pilcher, 1998).

\section{RESEARCH QUESTIONS}

The subjected research is conducted to have an answer to the following research questions.

What are the factors contributing towards the purchase intention of the CF products?

What is the impact of each individual factors contributing towards the purchase of $\mathrm{CF}$ products?

\section{RESEARCH OBJECTIVES}

As mentioned earlier, CF products contributes to $70 \%$ of the purchase decisions; so, the study will be highlighting the possible factors which contributes towards the decision making while purchasing products. These factors will be judged individually by different statistical tools from the collected data from the targeted population.

\section{STUDY LIMITATIONS}

The current study is limited to the residents of Karachi. The questionnaire was designed specifically keeping in view the residents of Karachi. The population is kept small as the possible feedback can be in smaller number. Also, due to the lockdown situation; the research survey is not conducted physically limiting to the feedback only through social media. The possible feedback may not be as much reliable as people nowadays only get through these type of research surveys within no time just because they do not have time filling these type of questionnaires rather than wasting time in other activities. 


\section{RESEARCH MODEL}

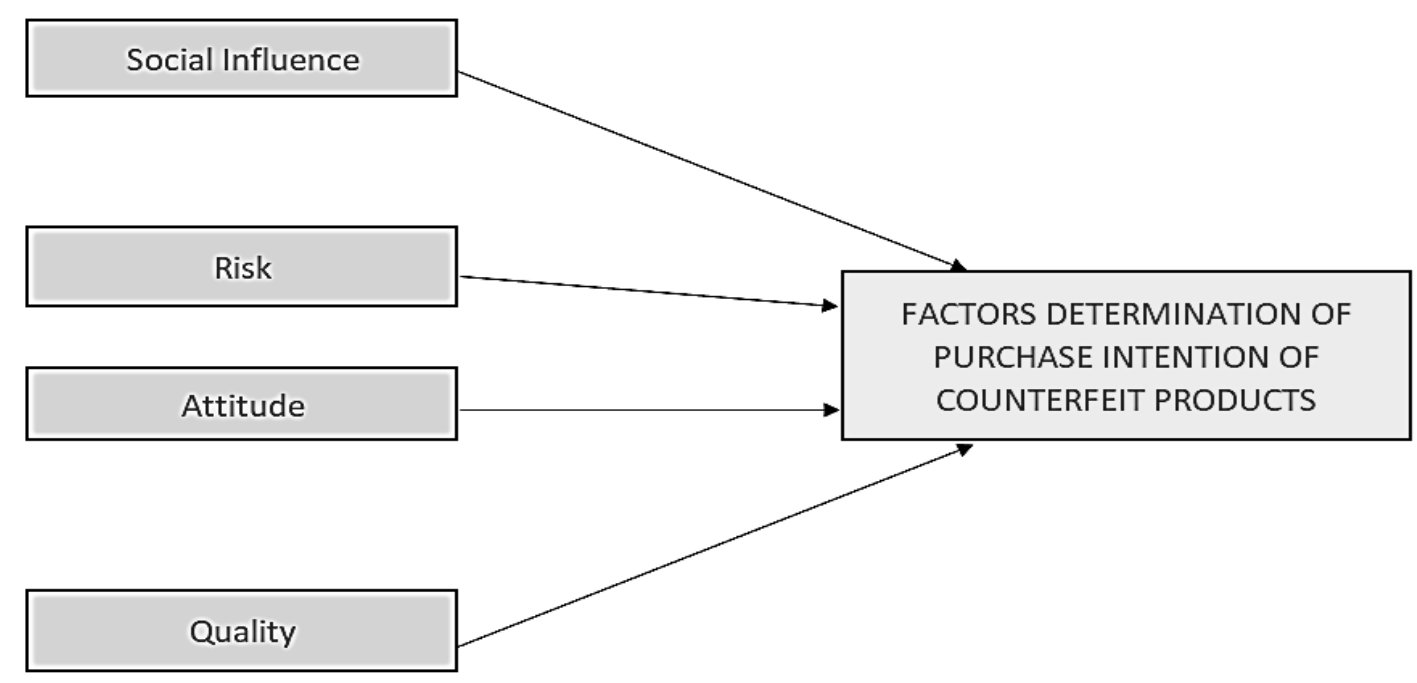

\section{RESEARCH HYPOTHESIS}

H1: Social Influence have a significant impact on the purchase intention of counterfeit products.

H2: Risk have a significant impact on the purchase intention of counterfeit products.

H3: Attitude have a significant impact on the purchase intention of counterfeit products.

H4: Quality have a significant impact on the purchase intention of counterfeit products.

\begin{tabular}{|l|l|l|}
\hline S. No. & HYPOTHESIS & REFERENCES \\
\hline 1. & Social Influence ---- $\rightarrow$ Buying intentions of CF products & Bhatia, V. (2018) \\
\hline 2. & Risk ---- $\rightarrow$ Buying intentions of CF products & Bhatia, V. (2018) \\
\hline 3. & Attitude ---- $\rightarrow$ Buying intentions of CF products & Bhatia, V. (2018), Viot, Le Roux, \& Kremer, (2014) \\
\hline 4. & Quality ---- $\rightarrow$ Buying intentions of CF products & Cademan, A., Henriksson, \& Nyqvist, (2012) \\
\hline
\end{tabular}

\section{LITERATURE REVIEW}

The history of the counterfeit products is vast as the technological advancement started in this materialistic world. Everyone in this world is copying of another and making profits without keeping in minds that they may fraud their market. Generally, the consumers buy CF products for various reasons and many theories developed in the past with potential reasons. Brief explanation of these theories is as follows: 


\section{Replica Theory}

Replica refers to the copy of something. So, this theory exactly fits to the concept of CF products as manufacturers claim that these are the master copy of the original branded products providing same level of services to the customers. The claimed prices are also higher but obviously cheaper than the original products (Ahmad, Shamsi, \& Sarah, 2016).

\section{Style Theory}

The other aspect of buying CF products is the affordability of branded products to express themselves as fashion oriented and to maintain the style that currently followed in the market (Eisend, 2019).

\section{Manipulation Theory}

The CF products are announced as the replica of the original brand with some manipulations. These manipulations provide same level of services as the original brands as per the manufacturers. All these statements are advertised either online or the shopkeepers selling them market (Khandeparkar \& Motiani, 2018).

\section{Shortage Theory}

In some circumstances, the consumers state the shortage of the original products in the market as to the main reason of buying these CF products. They claim that original products are short in the market, and they have visited everywhere for the purchase of the original product but the $\mathrm{CF}$ product they bought as they haven't found the original brand (Bian \& Moutinho, 2011).

Counterfeit products are the presence of the original products falling in 3 different categories. First category can be called as replica of the original products with same features as original one. These are expensive but cheaper than the original ones. Second category are neither of very good quality nor the bad quality and are affordable. Last category is of worst quality which can be identified easily and are cheaper as well (d'Astous \& Gargouri, 2001).

Social Influence basically refers to the social status of the community buying the CF products. The social status greatly affects the buying behavior of the CF products. It showcases the value and background of an individual in the society (Çekirdekci \& Latif, 2019). The social class is categorized as below: 
- Upper Class: It describes the richest community with holds a prominent position in the society.

- Middle Class: These are neither rich nor poor.

- Lower Class: These are poor and holds instability regarding financial issues (Tang, Ing, \& Zaichkowsky, 2014).

CF products also have many risks nowadays as the technological advancement makes it easier for anyone to modify or copy products to such extent that people can't identify the original or copy. This increases the risk of fraud claiming the copy products as the original one and people buy those products believing that these are original or first copy for the specific product. CF products also have some limitations like they can cause allergies in case of the cosmetics etc. (Quoquab, Farzanan, Mohammad, \& Thurasamy, 2017)

Quality plays an important role in the development of trust in consumer's mind. CF products claim that same level of service will be provided as the original one. So, this is very important that same level should be provided to enhance sales. The quality of original products is high. They are durable and safe if consider cosmetics. In most cases, the original products provide extraordinary services which are required from the consumer's perspective (Wyld, 2008).

On contrary, the CF products are exactly same in presence but provides lower level of services compared to the original ones. They can create issues within shorter period of usage and may not be reliable as the original ones. Also, the quality of the raw material is not same as the original one which may affect the consumer's health (Yoo \& Lee, 2009).

\section{RESEARCH METHODOLOGY}

\section{Research Design}

This refers to the category of research in which the subjected study falls like qualitative or quantitative. As the research is conducted to check the validation of the variables adopted keeping in view the literature, therefore, the research is quantitative because the purpose of quantitative research is theory testing which we are carrying out in our research rather than to develop a theory which is qualitative type of research.

\section{Method of Research}

The method used in this research is observational because a questionnaire was developed to get feedback from the population of the research study. Therefore, feedback was collected based on 
the observation of the population under research. A questionnaire comprising of 25 behavioural and 7 demographical questions was developed and rotated via social platform to get the feedback.

\section{Objective of Research}

Objective of research can be of 3 types i.e., Explanatory, Exploratory and descriptive. Considering the aims of this research study, the objective of the research is explanatory as the research is used to test the historical studies developed regarding the current research problem statement. In short, this research is used to test and validate the previous research models and concluding the most important factor impacting the purchasing intention of CF products.

\section{Scope/Utility of Research}

This research study will suggest the most important factor contributing towards the decision making of the consumer buying CF products. Therefore, brands producing CF products may utilize the concluding remarks with variable impacting the highest on the purchasing decision. In result, they may target that specific factor to increase their market share by producing as per the consumer's demands. Therefore, the scope is limited to the firms producing the CF products and targeting them into the market.

\section{Technique Research}

The technique used in this research is primary as the targeted population was supposed to be the CF consumers. Therefore, the collected feedback is from the primary consumer. Hence, a questionnaire was the basic way of collecting the responses from the general targeted population i.e., residents of Karachi buying CF products.

\section{Approach of Research}

The research approach can be categorized as inductive and deductive. As the subjected research is carried out to test the theories developed in history, therefore, nature of this research is deductive as we have deduced our research model based on the past theories.

\section{Philosophy of Research}

The philosophy of the research is categorized as pragmatism, positivism, realism and interpretivism. Taking the objectives of the research into consideration, the research philosophy is 
interpretivism with the essence of subjectivism. Since, the data in collected to interpret the results obtained after analyzation, therefore, interpretivism research philosophy is followed.

\section{Sampling Design and Technique}

The sampling technique used in this research is probability sampling techniques accompanied by the convenient sampling. A questionnaire was developed and rotated through social platforms considering the convenience of getting the feedback.

\section{Sample Size}

The sample size is calculated based on the margin of error, confidence level, population size and the response distribution. Since the exact population was not known, therefore the population was assumed to be 20,000 with $95 \%$ confidence level, $5 \%$ error margin and 50\% response distribution.

\section{Instrumentation}

This study comprises of four independent and one independent variable. The details of the included variable are mentioned in below table.

\begin{tabular}{|c|c|c|c|c|}
\hline S. No. & Variable & Type & Scaling & References \\
\hline 1. & Social Influence & Independent & \multirow{5}{*}{$\begin{array}{l}\text { Likert Scale } \\
1 \rightarrow \text { Str. Disagree } \\
2 \rightarrow \text { Disagree } \\
3 \rightarrow \text { Somewhat Disagree } \\
4 \rightarrow \text { Neither disagree nor Agree } \\
5 \rightarrow \text { Somewhat Agree } \\
6 \rightarrow \text { Agree } \\
7 \rightarrow \text { Str. Agree }\end{array}$} & Bhatia, (2018) \\
\hline 2. & Risk & Independent & & Bhatia, (2018) \\
\hline 3. & Attitude & Independent & & Bhatia (2018) \\
\hline 4. & Quality & Independent & & $\begin{array}{l}\text { Cademan, A., Henriksson, \& } \\
\text { Nyqvist, (2012) }\end{array}$ \\
\hline 5. & Purchasing Intention & Dependent & & Bhatia, V. (2018) \\
\hline
\end{tabular}

\section{STATISTICAL TESTING}

Reliability test is performed to check the authenticity and relationship strength for each item of the questionnaire. Therefore, below output results have been obtained after performing the reliability test. After the collection of data from the targeted population, different statistical tests have been performed like descriptive statistics, correlation, regression etc. to check the relationship of variables in between them and to derive conclusions based on the test results. 
Table 1. Construct Relibility - Social Influence

Reliability Statistics

\begin{tabular}{|r|r|r|}
\hline Cronbach's Alpha & $\begin{array}{c}\text { Cronbach's Alpha Based on } \\
\text { Standardized Items }\end{array}$ & N of Items \\
\hline .597 & .609 & 4 \\
\hline
\end{tabular}

Source: Study Analysis

Item-Total Statistics

\begin{tabular}{|l|r|r|r|r|}
\hline & $\begin{array}{c}\text { Scale Mean if Item } \\
\text { Deleted }\end{array}$ & $\begin{array}{c}\text { Scale Variance if } \\
\text { Item Deleted } \\
\text { Total Correlation }\end{array}$ & $\begin{array}{c}\text { Corrected Item- } \\
\text { if Item Deleted }\end{array}$ \\
\hline SI_1 & 15.460 & 11.088 & .263 & .626 \\
SI_2 & 14.828 & 11.423 & .334 & .559 \\
SI_3 & 14.908 & 10.177 & .522 & .417 \\
SI_4 & 14.805 & 10.996 & .425 & .492 \\
\hline
\end{tabular}

Social Influence (If item deleted)

Table 2. Construct Reliability- Risk

Reliability Statistics

\begin{tabular}{|r|r|r|}
\hline Cronbach's Alpha & $\begin{array}{c}\text { Cronbach's Alpha Based on } \\
\text { Standardized Items }\end{array}$ & N of Items \\
\hline .676 & .678 & 4 \\
\hline
\end{tabular}

Item-Total Statistics

\begin{tabular}{|l|r|r|r|r|}
\hline & $\begin{array}{c}\text { Scale Mean if } \\
\text { Item Deleted }\end{array}$ & $\begin{array}{c}\text { Scale Variance if } \\
\text { Item Deleted } \\
\text { Total Correlation }\end{array}$ & $\begin{array}{c}\text { Corrected Item- } \\
\text { Cronbach's } \\
\text { Alpha if Item } \\
\text { Deleted }\end{array}$ \\
\hline R_1 & 13.011 & 13.732 & .357 & .669 \\
R_2 & 13.448 & 11.553 & .584 & .530 \\
R_3 & 14.195 & 12.043 & .415 & .640 \\
R_4 & 13.862 & 11.097 & .492 & .587 \\
\hline
\end{tabular}

Reliability-Risk (If item deleted) 
Table 3. Construct Reliability- Attitude

Reliability Statistics

\begin{tabular}{|r|r|r|}
\hline Cronbach's Alpha & $\begin{array}{c}\text { Cronbach's Alpha Based on } \\
\text { Standardized Items }\end{array}$ & N of Items \\
\hline .868 & .866 & 4 \\
\hline
\end{tabular}

Table 4. Construct Reliability - Quality

Reliability Statistics

\begin{tabular}{|c|c|c|}
\hline Cronbach's Alpha & $\begin{array}{c}\text { Cronbach's Alpha Based on } \\
\text { Standardized Items }\end{array}$ & $\mathrm{N}$ of Items \\
\hline .934 & .935 & 5 \\
\hline
\end{tabular}

Table 5. Construct Reliability - Purchase Intention

Reliability Statistics

\begin{tabular}{|c|c|c|}
\hline Cronbach's Alpha & $\begin{array}{c}\text { Cronbach's Alpha Based on } \\
\text { Standardized Items }\end{array}$ & $\mathrm{N}$ of Items \\
\hline .901 & .904 & 4 \\
\hline
\end{tabular}

\section{RESULTS}

\section{Descriptive Statistics}

Descriptive statistics refers to the averages of the collected data from the research study. A total of 87 responses were received and analyzed in the descriptive perspective as mentioned in the below tables.

Table 6. Descriptive Statistics - Gender

\section{Gender}

\begin{tabular}{|c|c|c|c|c|c|}
\hline & & Frequency & Percent & Valid Percent & $\begin{array}{c}\text { Cumulative } \\
\text { Percent }\end{array}$ \\
\hline \multirow{3}{*}{ Valid } & Female & 17 & 19.5 & 19.5 & 19.5 \\
\hline & Male & 70 & 80.5 & 80.5 & 100.0 \\
\hline & Total & 87 & 100.0 & 100.0 & \\
\hline
\end{tabular}


Table 7. Descriptive Statistics - Age Groups

\begin{tabular}{|c|c|c|c|c|c|}
\hline \multicolumn{6}{|c|}{ Agegroupasof 2020} \\
\hline & & Frequency & Percent & Valid Percent & $\begin{array}{c}\text { Cumulative } \\
\text { Percent }\end{array}$ \\
\hline \multirow{6}{*}{ Valid } & $<20$ & 1 & 1.1 & $\overline{1.1}$ & $\overline{1.1}$ \\
\hline & $>35$ & 9 & 10.3 & 10.3 & 11.5 \\
\hline & $20-25$ & 26 & 29.9 & 29.9 & 41.4 \\
\hline & $25-30$ & 44 & 50.6 & 50.6 & 92.0 \\
\hline & $30-35$ & 7 & 8.0 & 8.0 & 100.0 \\
\hline & Total & 87 & 100.0 & 100.0 & \\
\hline
\end{tabular}

Table 8. Descriptive Statistics - Overall

\begin{tabular}{|c|c|c|c|c|c|c|c|c|c|}
\hline \multicolumn{10}{|c|}{ Descriptive Statistics } \\
\hline & $\mathrm{N}$ & Minimum & Maximum & Mean & Std. Deviation & \multicolumn{2}{|c|}{ Skewness } & \multicolumn{2}{|c|}{ Kurtosis } \\
\hline & Statistic & Statistic & Statistic & Statistic & Statistic & Statistic & Std. Error & Statistic & Std. Error \\
\hline MeanSI & 87 & 2.00 & 7.00 & 5.0000 & 1.03430 & -.855 & .258 & .526 & .511 \\
\hline MeanR & 87 & 2.00 & 7.00 & 4.5431 & 1.10180 & -.111 & .258 & -.472 & .511 \\
\hline MeanATT & 87 & 1.00 & 6.00 & 3.8046 & 1.40205 & -250 & .258 & -.954 & .511 \\
\hline MeanQ & 87 & 1.0 & 6.2 & 3.708 & 1.4418 & -.130 & .258 & -.938 & .511 \\
\hline MeanPI & 87 & 1.00 & 6.25 & 3.7184 & 1.29949 & -.100 & .258 & -.375 & .511 \\
\hline Valid N (listwise) & 87 & & & & & & & & \\
\hline
\end{tabular}

The results show that $80.5 \%$ of the respondents were male while $19.5 \%$ comprises of female respondents.

\section{Inferential Analysis}

For the inferential tests, MLR is selected to check the important factor which can considered by $\mathrm{CF}$ product manufacturers to increase their market and sales.

Table 9. Variable's Summary-MLR

\begin{tabular}{|l|l|l|l|}
\hline Model & Variables Entered & Variables Removed & Method \\
\hline 1 & Mean Q, Mean SI, Mean R, Mean ATTb &. & Enter \\
\hline
\end{tabular}

Variables Removed/Entered

Table 10. Model Summary-MLR

Model Summary

\begin{tabular}{|l|l|l|l|l|}
\hline Model & R & R Square & Adjusted R Square & $\begin{array}{l}\text { Std. Error of the } \\
\text { Estimate }\end{array}$ \\
\hline 1 & $.891^{\mathrm{a}}$ & .794 & .784 & .60423 \\
\hline
\end{tabular}


Table 11. ANOVA

\begin{tabular}{|c|c|c|c|c|c|c|}
\hline \multicolumn{7}{|c|}{ ANOVA $^{a}$} \\
\hline Model & & Sum of Squares & $\mathrm{df}$ & Mean Square & $\mathrm{F}$ & Sig. \\
\hline \multirow{3}{*}{1} & Regression & 115.288 & 4 & 28.822 & 78.945 & $.000^{\mathrm{b}}$ \\
\hline & Residual & 29.937 & 82 & .365 & & \\
\hline & Total & 145.226 & 86 & & & \\
\hline
\end{tabular}

Table 12. MLR

Coefficients

\begin{tabular}{|ll|l|l|l|l|l|}
\hline \multirow{2}{*}{ Model } & \multicolumn{2}{|l|}{ Unstandardized Coefficients } & $\begin{array}{l}\text { Standardized } \\
\text { Coefficients }\end{array}$ & & Sig. \\
\cline { 2 - 5 } & & B & Std. Error & Beta & & \\
\hline & (Constant) & .748 & .460 & & 1.627 & .108 \\
1 & Mean SI & .069 & .065 & .055 & 1.060 & .292 \\
& Mean R & -.063 & .062 & -.054 & -1.017 & .312 \\
& Mean ATT & .040 & .090 & .043 & .440 & .661 \\
& Mean Q & .746 & .087 & .827 & 8.556 & .000 \\
\hline
\end{tabular}

The test value of 0.794 for R-Square explains that developed model by independent variables fits to $79.4 \%$ of the dependent variable. Also, the sig value of 0.000 concludes that independent variables have a significant impact on the purchase intentions of the CF consumers. Going more precise, the quality is the most important factor which has a significant impact on the purchasing intention of CF products as its sig value is less than 0.05 .

\section{Hypothesis Assessment Summary}

After the obtained results from the MLR, since the p-values for Social Influence, Risk and attitude are greater than the significance level, therefore we are unable accept the alternative hypothesis. Also, since the p-value for quality is less than 0.05; therefore, we accept the alternative Hypothesis. Hence, there is a significant relationship between quality and the purchase intention of $\mathrm{CF}$ consumers.

\section{DISCUSSION AND CONCLUSION}

As per the findings, the quality is concluded as the most important factor which is having great impact on the purchasing behavior of the CF products. The correlation results Show that there is a positive strong correlation of social influence and attitude with other variables. Furthermore, profit will enhance if the consumers requirements are fulfilled which we can merge it into a single Word of quality. Hence, firms producing CF products need to focus on the quality to achieve the higher market share. 
We can conclude that firms seeking for higher profit margins need to focus on the quality of the $\mathrm{CF}$ products in a broader perspective. Once they get quality as their first choice, they will get higher returns in terms of profit.

\section{FUTURE RESEARCH DIMENSIONS}

This research study was conducted assuming to be the CF consumer target residents of Karachi, therefore if any firm have plan to improve their sales and profit margins; they can consider the implications of the research. Nowadays, the customers want their requirements to be fulfilled in any way, therefore quality is a biggest challenge for the manufacturing firms. 


\section{REFERENCES}

Ahmad, N., Shamsi, A., \& Hussain, S. (2016). Impact of Counterfeit Products on Consumer Buying Behavior: Empirical Investigation form Karachiites. Grassroots, 50(1).

Bian, X., \& Moutinho, L. (2011). Counterfeits and branded products: effects of counterfeit ownership. Journal of Product \& Brand Management.

Bhatia, V. (2018). Examining consumers' attitude towards purchase of counterfeit fashion products. Journal of Indian Business Research

Cademan, A., Henriksson, R., \& Nyqvist, V. (2012). The effect of counterfeit products on luxury brands: An empirical investigation from the consumer perspective.

Çekirdekci, Ş. O., \& Latif, F. O. B. (2019). Users and non-users of counterfeits: motivations, emotional outcomes and neutralization processes. Journal of Product \& Brand Management.

d'Astous, A., \& Gargouri, E. (2001). Consumer evaluations of brand imitations. European Journal of Marketing, 35(1/2), 153-167.

Eisend, M. (2019). Gender roles. Journal of Advertising, 48(1), 72-80.

Khandeparkar, K., \& Motiani, M. (2018). Fake-love: brand love for counterfeits. Marketing Intelligence \& Planning.

Nguyen, P. V., \& Tran, T. T. (2013). Modeling of determinants influence in consumer behavior towards counterfeit fashion product. Business Management Dynamics, 2(12), 12-23.

Nia, A., \& Zaichkowsky, J. L. (2000). Do counterfeits devalue the ownership of luxury brands? Journal of Product \& Brand Management, 9(7), 485-497.

Quoquab, F., Farzanan, S., Mohammad, J., \& Thurasamy, R. (2017). Factors affecting consumers' intention to purchase counterfeit product. Asia Pacific Journal of Marketing and Logistics, 29(4), 837-853.

Tang, F., Tian, V. I., \& Zaichkowsky, J. (2014). Understanding counterfeit consumption. Asia Pacific Journal of Marketing and Logistics. 
Tom, G., Garibaldi, B., Zeng, Y., \& Pilcher, J. (1998). Consumer demand for counterfeit goods. 15(5), 405-421.

Viot, C., Le Roux, A., \& Kremer, F. (2014). Attitude towards the purchase of counterfeits: Antecedents and effect on intention to purchase. Recherche et Applications en Marketing (English Edition), 29(2), 3-31.

Wyld, D. C. (2008). Why safeguarding the pharmaceutical supply chain from counterfeit drugs with RFID is vital chain from counterfeit drugs with RFID is vital of the pharmaceutical industry. International Business Journal, 18(3), 206-216.

Yoo, B., \& Lee, S. H. (2009). Buy genuine luxury fashion products or counterfeits? Association For Consumer Research, 36(281), 280-286. 